\title{
Structural Styles and Petroleum Potential of Miano Block, Central Indus Basin, Pakistan
}

\author{
Saif-Ur-Rehman K. Jadoon', Muhammad F. Mehmood², Zohaib Shafiq², Ishtiaq A. K. Jadoon' \\ ${ }^{1}$ Department of Earth Sciences, COMSATS Institute of Information Technology, Abbottabad, Pakistan \\ ${ }^{2}$ Department of Earth and Environmental Sciences, Bahria University, Islamabad, Pakistan \\ Email: saif_jadoon@outlook.com
}

How to cite this paper: Jadoon, S.-U.-R.K., Mehmood, M.F., Shafiq, Z. and Jadoon, I.A.K. (2016) Structural Styles and Petroleum Potential of Miano Block, Central Indus Basin, Pakistan. International Journas of Geosciences, 7, 1145-1155.

http://dx.doi.org/10.4236/ijg.2016.710086

Received: July, 1, 2016

Accepted: October 16, 2016

Published: October 19, 2016

Copyright $\odot 2016$ by authors and Scientific Research Publishing Inc. This work is licensed under the Creative Commons Attribution International License (CC BY 4.0).

http://creativecommons.org/licenses/by/4.0/ (c) (i) Open Access

\begin{abstract}
The main purpose of this research article is to evaluate the structural styles and hydrocarbon potential of Miano Block using seismic and well log data. The Miano Block discovered in 1993 is located in the Central Indus Basin which is a part of an extensional regime exhibiting normal faulting, formed as a result of split of the Indian Plate firstly from Africa and then from Madagascar and Seychelles. Tectonically, the Miano Block lies on the Panno-Aqil graben between two extensive regional highs i.e. Jacobabad-Khairpur High and Mari Kandhkot High. Four migrated seismic lines were used for structural enhancement; P2092-111, P2092-113 and P2092-115 (dip lines) and P2092-110 (strike line). Time and depth contours were generated for four horizons, HabibRahi Formation, Sui Main Limestone, Ranikot Formation and Lower Goru Formation which showed the presence of horst and graben structures in the subsurface. The interpretation of horst and graben structures is based on a parallel set of NS-oriented high-angle planar normal faults with dips either towards SE or SW with majority of the faults dipping towards the SW. The faults are observed to exhibit slight disruption of strata with limited displacement to the order of about 50 $m$ in Lower Goru Formation. Thus, horst and graben structures with NS trend in the study area are interpreted. The NS trend of these structures along with similar structural dip is inconsistent to the NW-SE orientation of regional structures i.e. PannoAqil graben and the Jacobabad-Kharipur and Mari-Kandhkot Highs indicating about the presence of a second minor set of faults and complexity of deformation. In this setting, Maino-02 well was drilled with the primary target as B-Sands of Lower Goru Formation belonging to Lower Cretaceous age while secondary target was A-Sands of Lower Goru belonging to the same age. The result of the petrophysical analysis supports two potential zones (zone 1 and zone 2) within the Lower Goru Formation. Potential reservoir zones were marked with average hydrocarbon saturation of zone 1 calculated as $63.5 \%$ and that of zone 2 as $68.9 \%$.
\end{abstract}




\section{Keywords}

Extensional Regime, Horst and Graben

\section{Introduction}

The Miano gas field is located in the Central Indus Basin having a total area of 814.02 sq. km (Figure 1). Tectonically the block lies on Panno-Aqil graben between two highs i.e. Jacobabad-khairpur and Mari-Kandhkot (Figure 2(a)). Thar Desert lies in its south and Delhi Aravalli range is in its east.

The Maino-02 well was drilled with the primary target as B-Sands of Lower Goru Formation belonging to Lower Cretaceous age and secondary target as A-Sands of Lower Goru Formation of the same age. The total depth of the well was $3548.4 \mathrm{~m}$ and

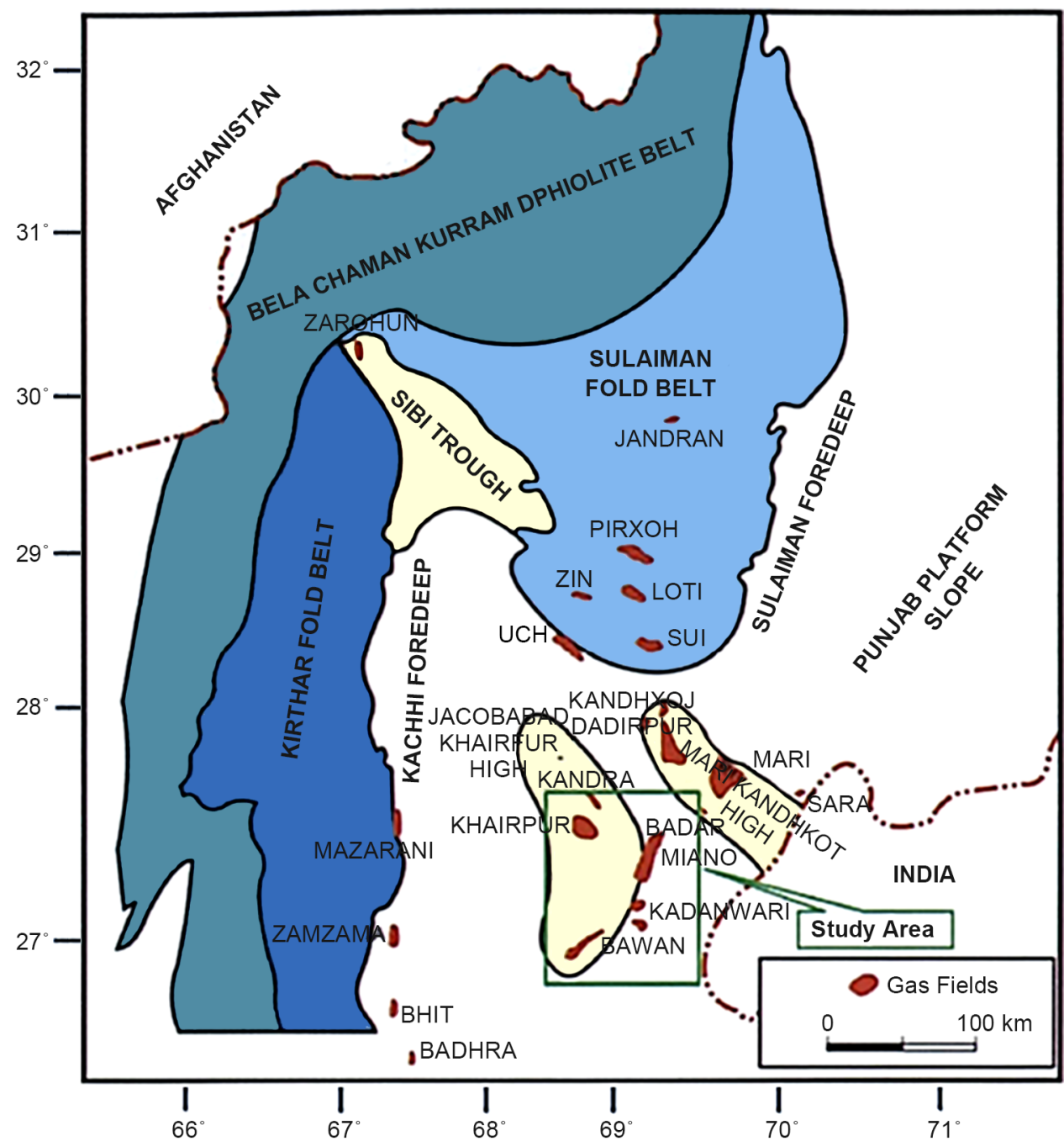

Figure 1. Generalized regional tectonic map with location of major oil and gas fields in the study area (modified after Ahmed et al., 2013) [1]. 


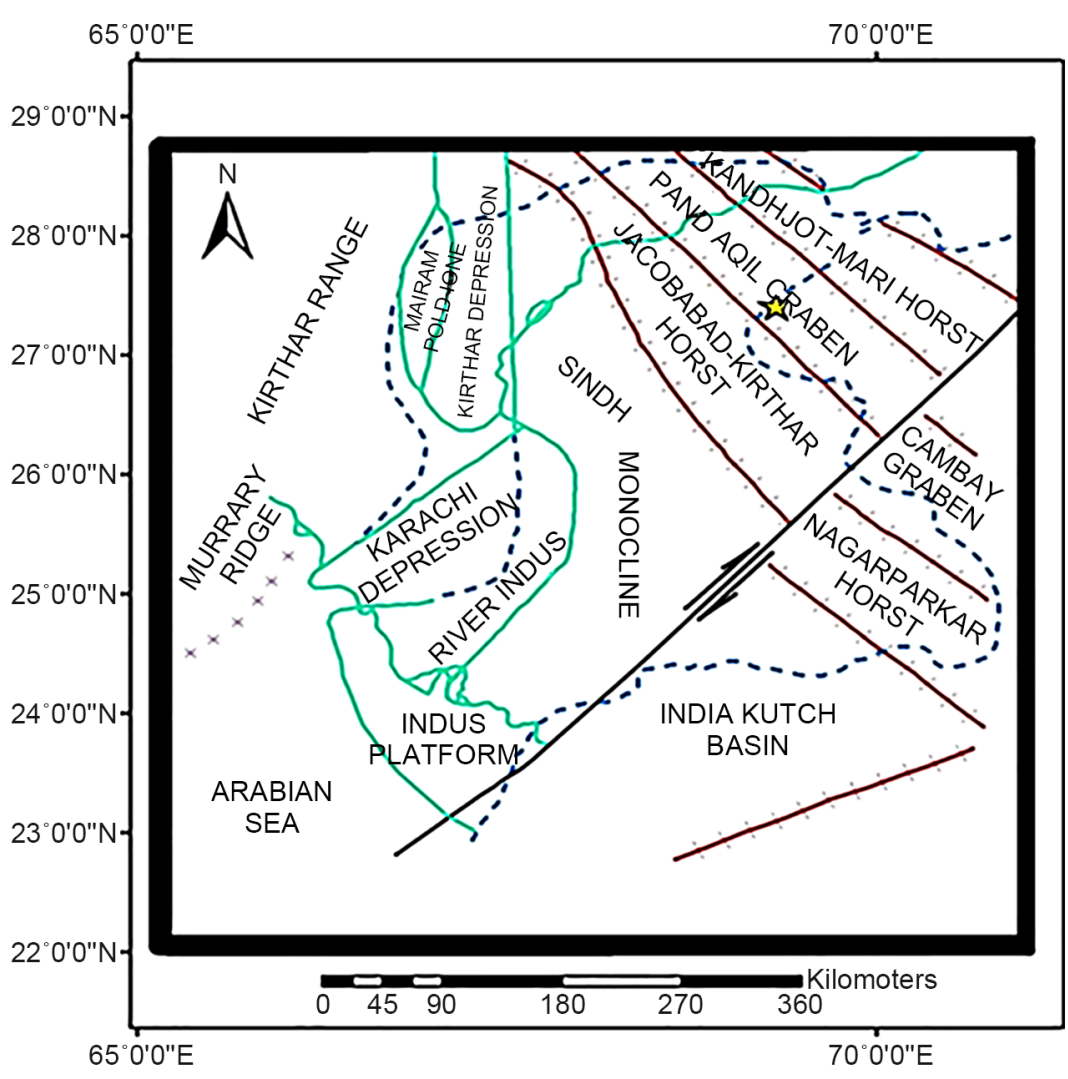

(a)

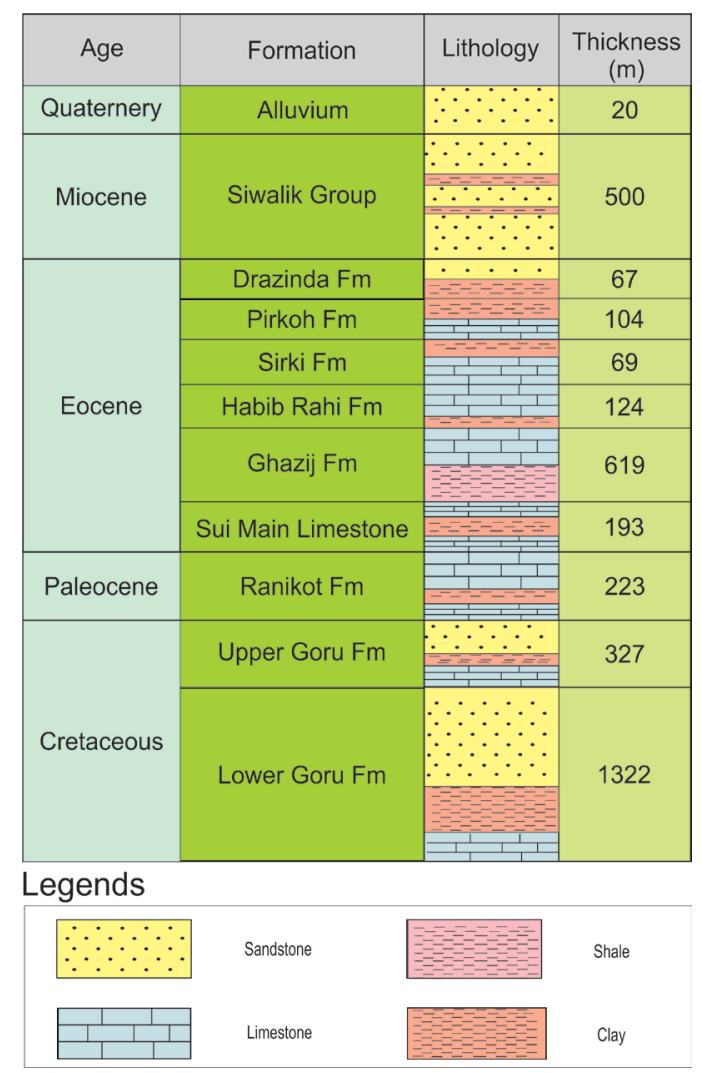

(b)

Figure 2. (a) Generalized tectonic map of the study area and adjoining regions in the Central Indus Basin. Study area is located on PanoAqil Graben in between Mari-Kandhkot Horst and Jacoababad-Kirthar Horst [6], (b) Stratigraphic column of Miano-02.

the drilling result was gas discovery. OMV Pakistan, Oil and Gas Development Company Limited (OGDCL), ENI Pakistan Limited and Pakistan Petroleum Limited (PPL) are the operators in Miano development and production with working interest of $17.68 \%, 52 \%, 15.16 \%$ and $15 \%$ respectively.

The study area is gas prone and has structural as well as stratigraphic trap. We have used seismic and well data for structural review and to understand the petroleum system of the Miano Gas Field with objectives as: 1) seismic data interpretation of the area in order to understand the presence, geometry and subsurface structural trends, 2) structural; analysis, and 3) demarcate suitable reservoir zones of the Lower Goru Formation to evaluate the quality of reservoir along with its porosity and hydrocarbon potential.

\section{Regional Geology and Tectonic Settings}

Study area is located in Central Indus Basin Pakistan. Figure 2(a), Figure 2(b) illustrates the main tectonic and stratigraphic elements of Central Indus Basin with the presence of regional basement highs as Jacobabad-Khairpur and Mari-Kandhkot Highs. The basin is bounded by Indian Shield to the east and highly folded mountains of Axial Belt to the west [2]. The general west directed dip of Sindh Platform is interrupted by gentle arch of north to south oriented Khairpur High which is interpreted as a large 
basement induced structure [3]. West of the Khairpur High, the Sindh Platform resumes its westward dip, forming a monotonous monocline dipping towards Kachi Foredeep. This Foredeep represents an asymmetric molasse basin with its deepest part closest to Kirthar Fold Range. The Jacobabad-Khairpur High, a combined gravity and magnetic anomaly is a relatively gentle arch and has been interpreted as being caused by a deep seated source. It separates the Karachi Foredeep from Sulaiman Foredeep and was most active during the Mesozoic and Lower Tertiary time, as evidenced by the base Tertiary unconformity [4]. The Kirthar Fold Belt is characterized by large northnorthwest to south-southeast oriented anticlines composed of sediments of Mesozoic to Neogene age. The Suleiman lobe has been interpreted as a structure over thrust on Indian Platform [5]. The development of the Suleiman fold belt is attributed to the plate geometry and transgression at the western end of the Indian plate. Whereas the development of the structural highs such as Jacobabad-Khairpur may be attributed with the development of the passive margin along the Indian plate due to its northwards drift from Africa. From Jurassic to Late Cretaceous, the area of present Khairpur High has occupied a basinal position. The epicenter during lower Cretaceous caused by rapid subsidence was situated to the east of the high. During Early Tertiary, either extensional or wrench tectonics induced uplift leading to the development of structural highs and erosion of Upper Cretaceous Mughal Kot and Pab Formations. Normal faulting with a dominant NW-SE trend has taken place. Clastic sediments of Ranikoton lap the Base Tertiary unconformity. From Lower Eocene onwards to Middle Eocene, the area of present day Khairpur High occupied again a basinal position. The final uplift of Khairpur High started in the Oligocene as a result of the India-Eurasia continental collision along the western and northern basin margins and continued into late Cenozoic time.

\section{Seismic Reflection Profiles Well Data and General Observations}

Industry seismic reflection profiles and well data from the Central Indus Basin were made available for this project by the Landmark Resources (LMKR), Pakistan with prior permission from Directorate General of Petroleum Concession (DGPC).

The interpretation of the reflection data involves its expressions in geological terms. When completely carried out, it requires the fitting together of all pertinent geological and geophysical information into an integrated picture that is more complete and more reliable than either source is likely to give alone.

The Seismic reflection interpretation usually consists of calculating the position of and identifying geologically concealed interfaces or sharp transition zones from which seismic pulses return to the ground surface by reflection. The influence of varying geological condition is eliminated along the profiles to transform the irregular recorded travel times into acceptable subsurface models. This is very important for confident estimation of the depth and geometry of the bed rock or target horizons. The main purpose of seismic reflection survey is to reveal as clearly as possible, the structures and stratigraphy of the subsurface. The geological meanings of seismic reflection are simply 
an indication of different boundaries where there is a change in acoustic impedance. These observed contrasts are associated with different geological structures and stratigraphic contacts.

In the given data the total depth of the section is $5 \mathrm{sec}$ (TWT). Each reflector has been picked according to the time and interpreted in terms of velocity and depth. Four horizons $\mathrm{R}_{1}$ (HabibRahi Limestone), $\mathrm{R}_{2}$ (Sui Main Limestone), $\mathrm{R}_{3}$ (Ranikot Formation) and $\mathrm{R}_{4}$ (Lower Goru Formation) respectively were picked up on the strike line P2092-110 and dip lines P2092-111, P2092-113 and P2092-115 shown on the base map (Figure 3), the well Miano-02 lies on the dip line P2092-113 at shot point 470. The reflectors were strong enough to be picked due to variation in acoustic impedance that is eventually caused by changes in lithology.

The area was tectonically stable until the Jurassic and probably Early Cretaceous but rifting started to occur during the Late Cretaceous and Early Paleocene, the effects of which can be seen on the seismic section in the form of faults of dip-slip displacement,

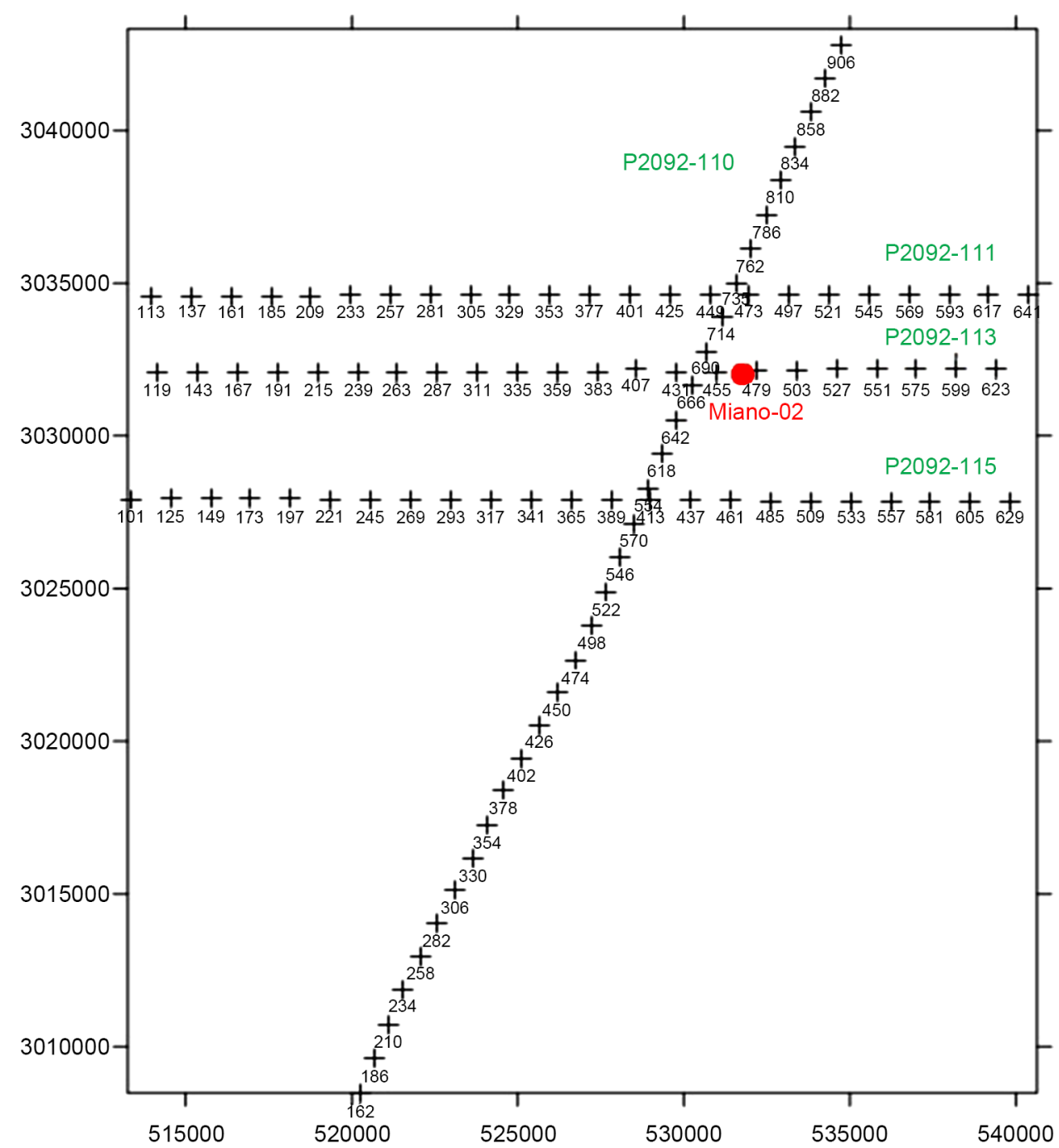

Figure 3. Seismic layout map of the study region. 
where the post Eocene strata are either not affected or very less deformed. Information about the description and deposition of rock units is available in literature [2].

Interpretation of seismic profiles reveals gentle structural dip towards the east with $\mathrm{N}-\mathrm{S}$ oriented high angle normal faults that extend from the Cretaceous with a throw of about $50 \mathrm{~m}$ and die upwards out in the Eocene strata mainly above the Sui Main Limestone (Figure 4). The faults appear not to disrupt older Jurassic strata. It is probable if they sole-out in a detachment of Cretaceous Sembar shale, similar to ramp-flat-ramp geometry of an extensional system [7]. N-S oriented normal faults, responsible for the formation of horst and graben structures were marked on the basis of break in continuity of the reflections on the dip lines P2092-111, P2092-113 and P2092-115. Time/depth contour maps and 3D structure analysis of the four formations namely Habib Rahi Limestone, Sui Main Limestone, Ranikot Formation and Lower Goru Formation support the horst and graben structures that have formed due to an extensional regime in the area (Figure 5). Integration of seismic with borehole images and well logs is expected to contribute significantly to resolve issues related to faults trend, type, and nature, similar to their interpretation in the Zaur field [8].

In defining the petroleum system of the area, interpretation of horst and graben structures in dip lines is of primary importance. For generation of hydrocarbons, grabens are mainly kitchen area. High temperature gradient in graben also provides proper temperature for maturation of hydrocarbon. For generation of hydrocarbon, overburden in access as a result of subsidence providing sufficient pressure is required. The tilted fault blocks similar to a bookshelf model [7] as a result of extensional forces facilitate petroleum system by providing migration pathway for hydrocarbons [9].

Well bore data was interpreted to describe the physical properties and behavior of rocks, soils and fluids, focusing mainly on the calculation of hydrocarbon potential of the area. On the basis of petrophysical analysis Lower Goru sands were demarcated into two potential zones of interest (Table 1). With the help of the well data average porosity, volume of shale, hydrocarbon saturation and water saturation were calculated for sands of the potential reservoir mainly Lower Goru sands. Lower Goru Formation encountered in the Miano-02 has a thickness of about $1322 \mathrm{~m}$.

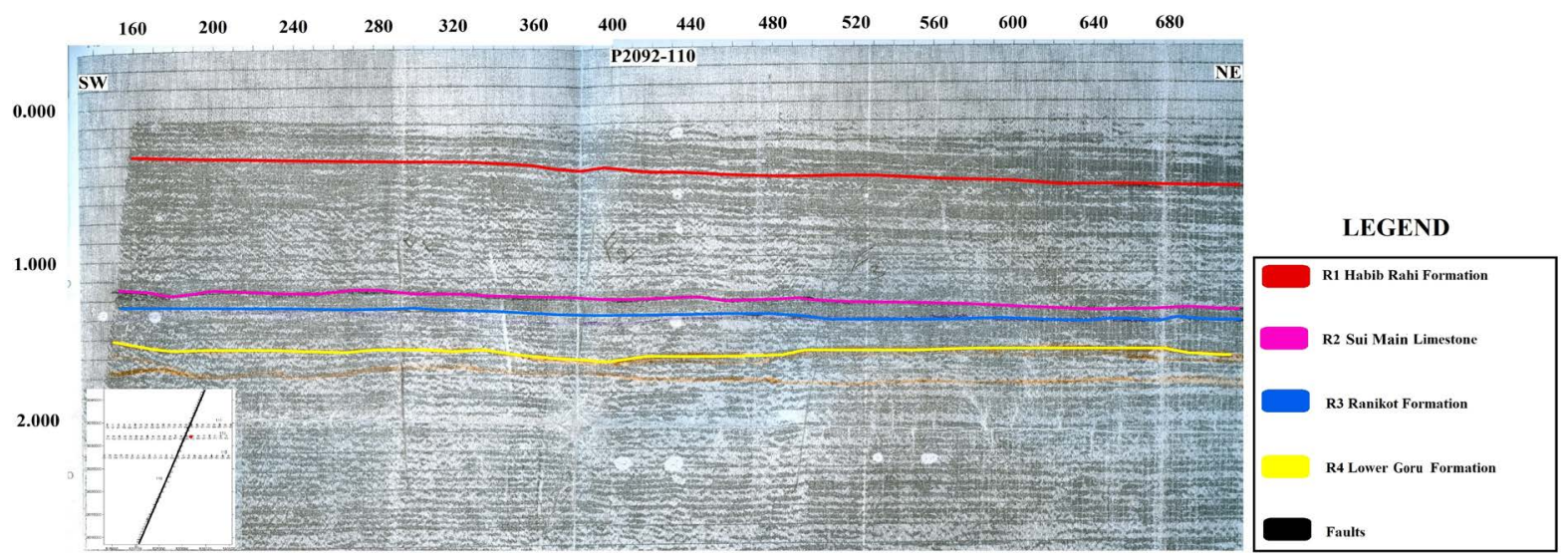

(a) 


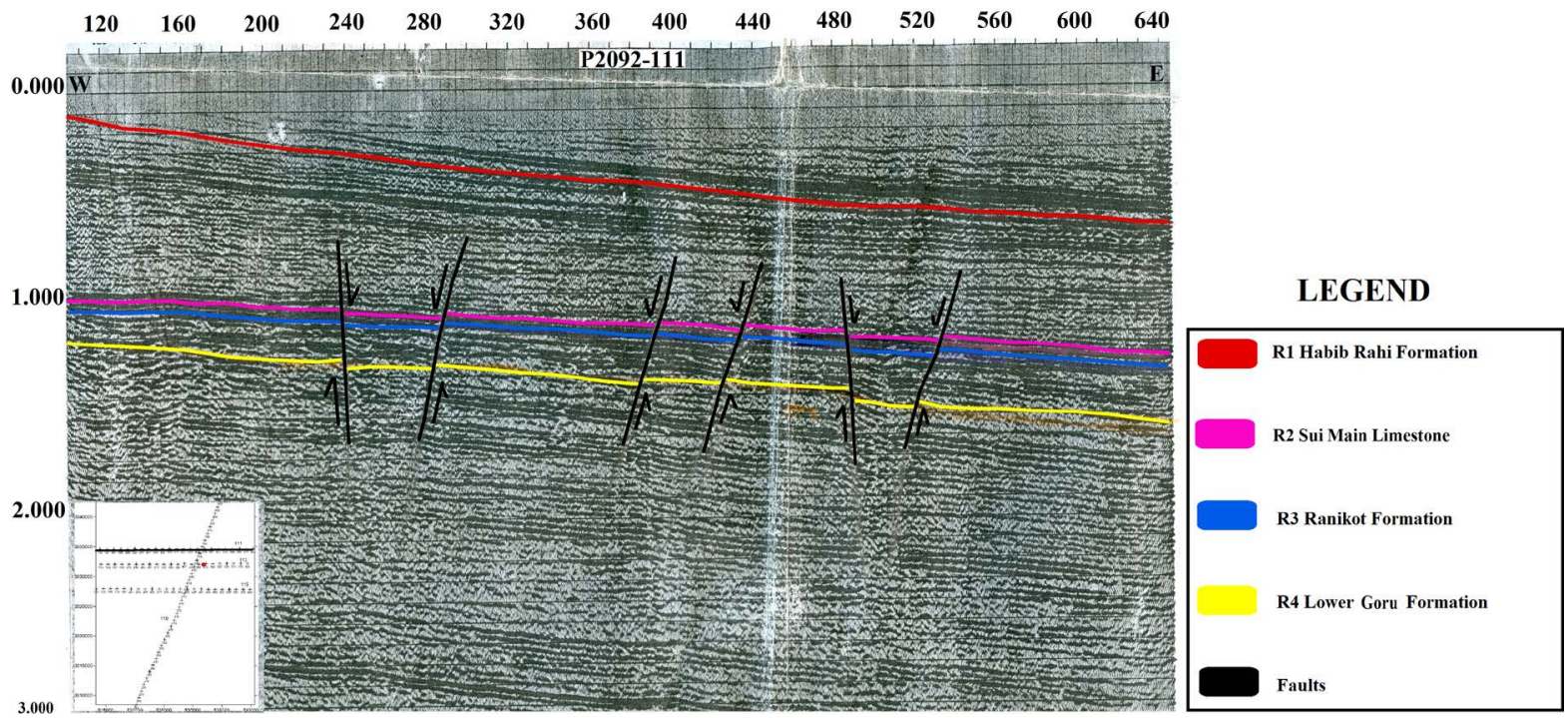

(b)

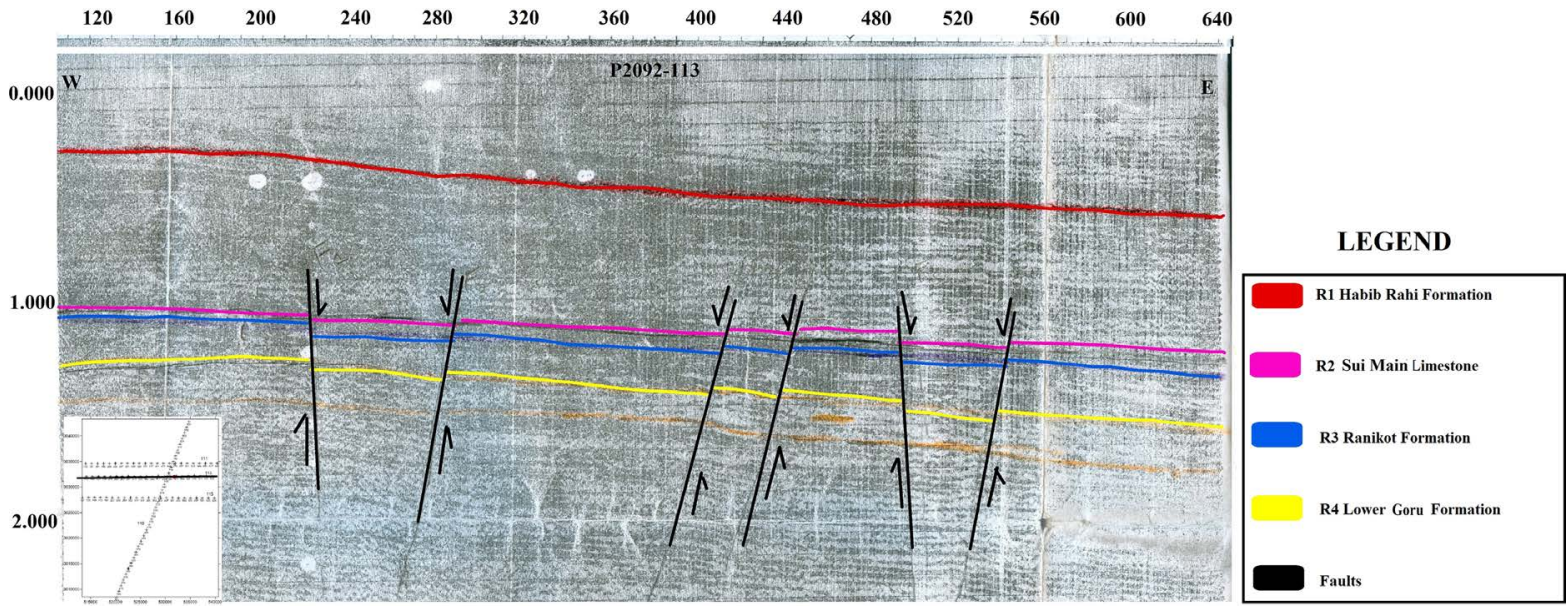

(c)

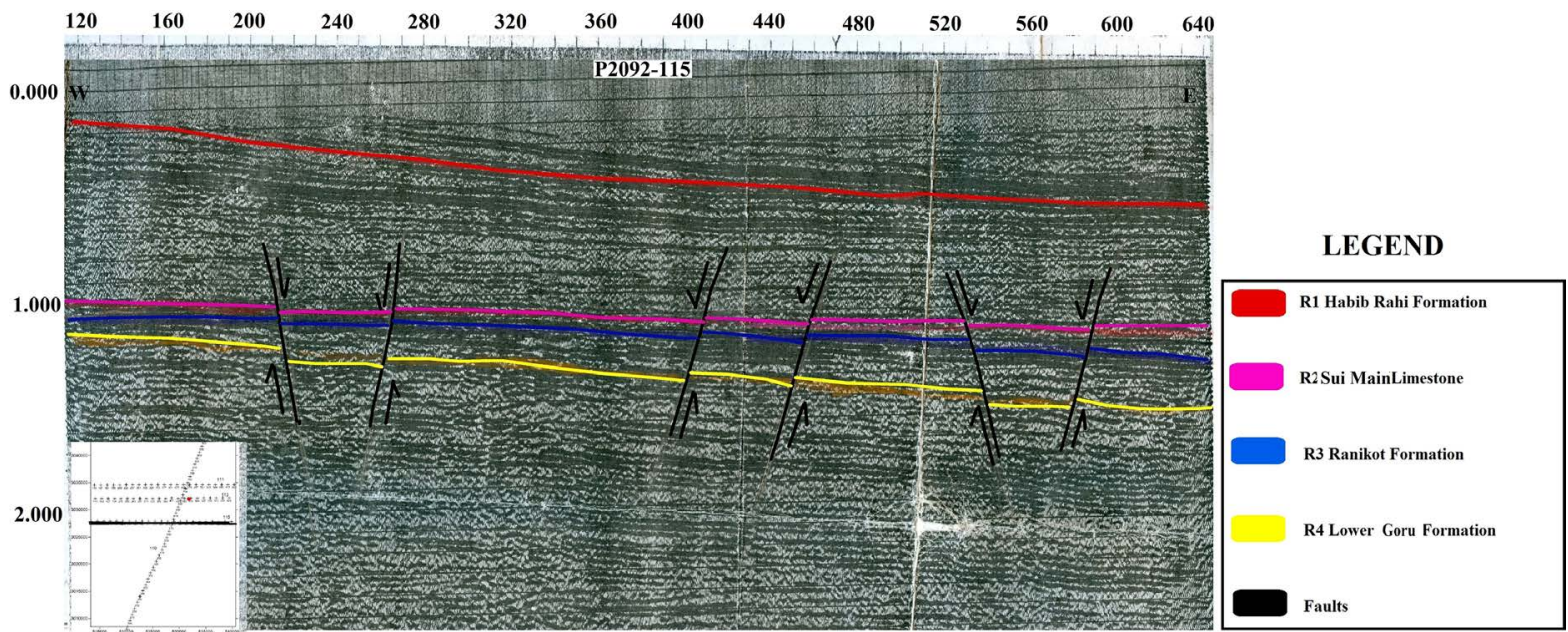

(d)

Figure 4. Seismic reflection data: (a) seismic strike line P2092-110, seismic dip lines (b) P2092-111, (c) P2092-113 and (d) P2092-115. 


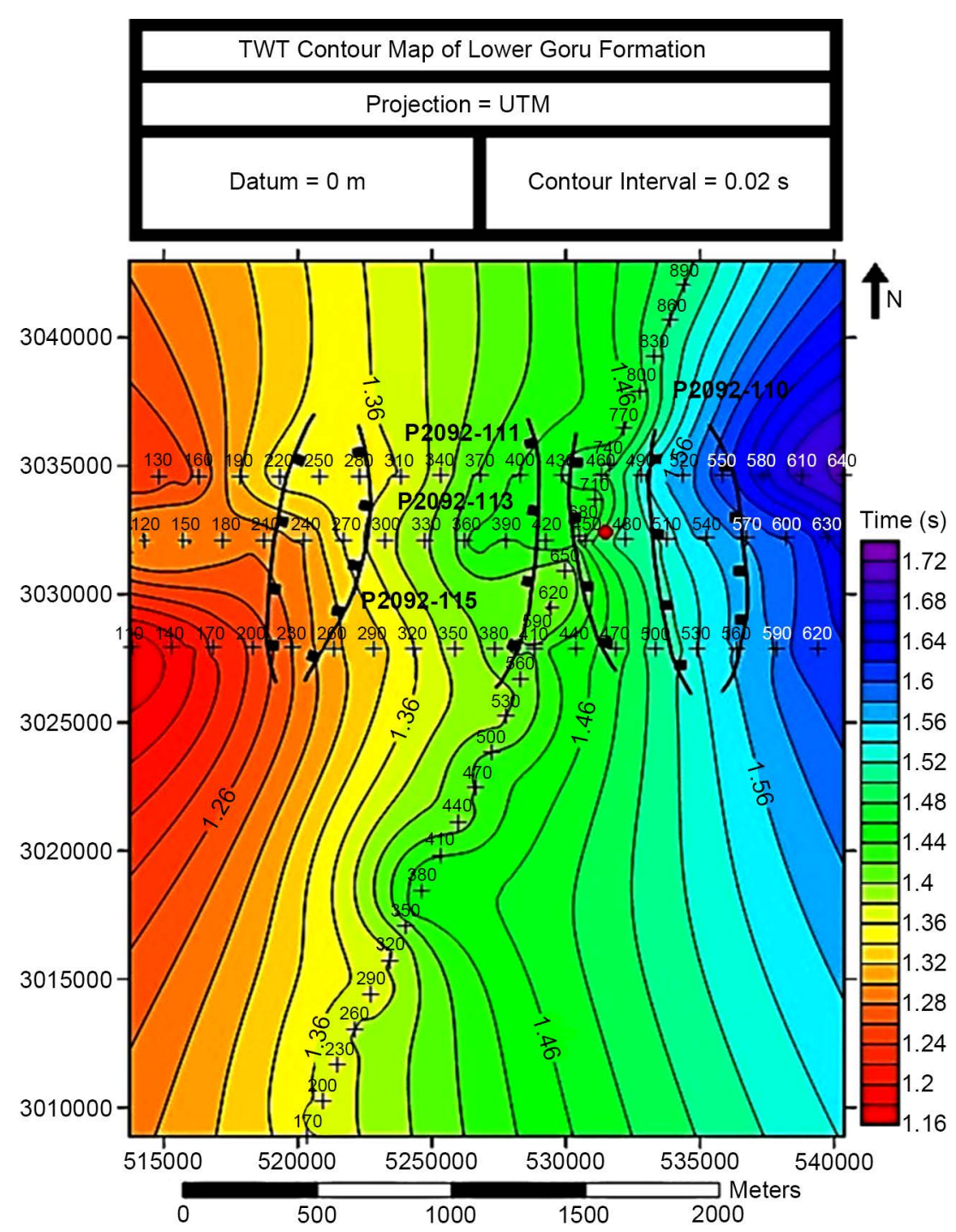

(a)

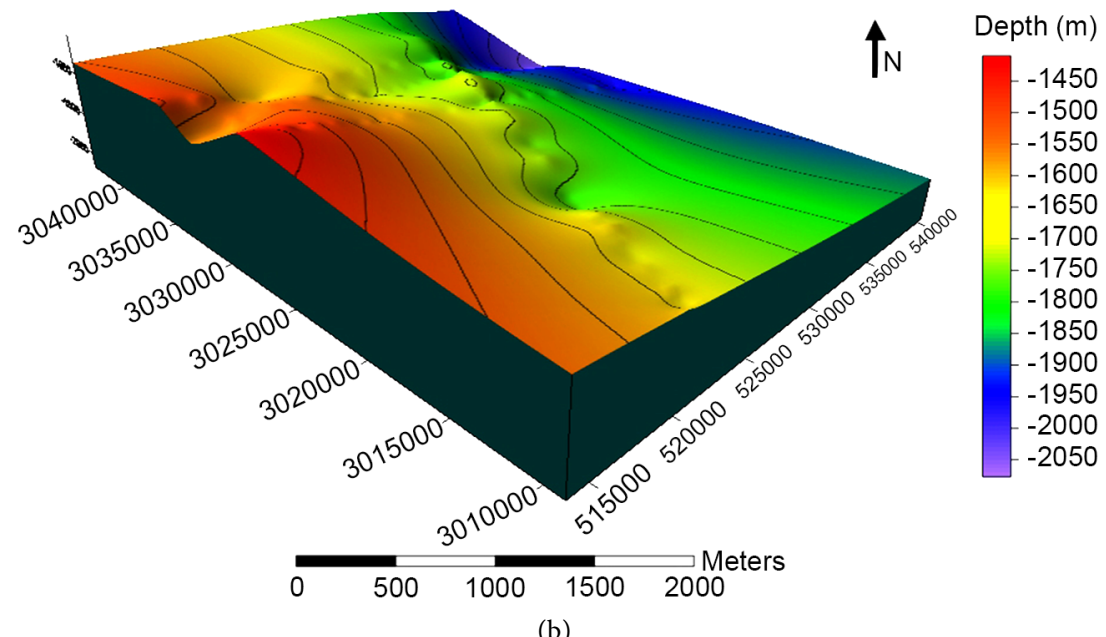

Figure 5. (a) Time contour map of Lower Goru Formation and fault system of NStrend, (b) 3D surface model of Lower Goru Formation. 
Table 1. Summary of zones of interest in Lower Goru Formation. Zone-01 is $275 \mathrm{~m}$ thick (3000 $3275) \mathrm{m}$, zone-02 is also $275 \mathrm{~m}$ thick (3275 - 3550) $\mathrm{m}$.

\begin{tabular}{cccccc}
\hline $\begin{array}{c}\text { Lower Goru } \\
\text { Formation }\end{array}$ & $\begin{array}{c}\text { Average Shale } \\
\text { Volume }\end{array}$ & $\begin{array}{c}\text { Average } \\
\text { Porosity }\end{array}$ & $\begin{array}{c}\text { Effective } \\
\text { Porosity }\end{array}$ & $\begin{array}{c}\text { Water } \\
\text { Saturation }\end{array}$ & $\begin{array}{c}\text { Hydrocarbon } \\
\text { Saturation }\end{array}$ \\
\hline Zone-01 & $33.34 \%$ & $15.25 \%$ & $9.29 \%$ & $36.41 \%$ & $63.59 \%$ \\
Zone-02 & $55.03 \%$ & $17.23 \%$ & $11.65 \%$ & $31.06 \%$ & $68.94 \%$ \\
\hline
\end{tabular}

Within the reservoir zone-01 of Lower Goru Formation, the overall concentration shows presence of $33.34 \%$ volume of shale with overall average distribution of porosity within the reservoir zone 1 being $15.25 \%$. Total hydrocarbon saturation present in this zone is $63.58 \%$. The graph trend indicates uniform hydrocarbon saturation, with saturation values ranging between $50 \%-80 \%$ (Figure $6(\mathrm{a})$ ). The overall trend indicates a good hydrocarbon potential in the area.

The reservoir zone-02 of Lower Goru Formation shows comparatively higher distribution of dirty formation compared to zone 1 of the reservoir, the average volume of shale present in the reservoir equals to $55.3 \%$ with the overall average distribution of porosity within the reservoir zone- 02 being $17.23 \%$. Hydrocarbon saturation is constrained in between $60 \%-80 \%$ at a depth of $3280 \mathrm{~m}-3350 \mathrm{~m}$ whereas at the depth of $3350 \mathrm{~m}-3525 \mathrm{~m}$ there is a gradual increase in hydrocarbon saturation to about $65 \%$ 90\% (Figure 6(b)). Total hydrocarbon saturation present in reservoir zone 2 is $68.97 \%$. The overall trend indicates that the hydrocarbon saturation within the reservoir zone-02 is higher compared to reservoir zone-01.

\section{Conclusions}

1) The seismic data interpretation of Miano area shows the presence of horst and graben structures, apparently restricted to the Cretaceous strata. It is probable if planar normal fault system soles out in a detachment of Sembar Formation.

2) A set of NS trending planar normal faults with a displacement of about $50 \mathrm{~m}$ have been interpreted with dips towards SW.

3) The 3D structural analysis shows gently dipping strata towards the east. Thus, up-dip migration of the hydrocarbons is predictable in the vicinity of the study area.

4) NS oriented normal faults are inconsistent with trends of regional structures i.e. Jacobabad-Khairpur High and Mari-Kandhkot High.

5) The average shale volume in zone-01 of Lower Goru Formation is 33.34\%, average porosity is $15.25 \%$, effective porosity is $9.29 \%$, average water saturation is 0.364 (36.4\%), and average hydrocarbon saturation is 0.635 (63.5\%).

6) The average shale volume in zone- 02 is $55.03 \%$, average porosity is $17.23 \%$, effective porosity is $11.65 \%$, average water saturation is $0.310(31 \%)$ and average hydrocarbon saturation is 0.689 (68.9\%).

7) The calculations performed for the petrophysical analysis elucidated that both of the reservoir zones i.e. zone-01 and zone-02 of the Lower Goru Formation have good hydrocarbon potential. 


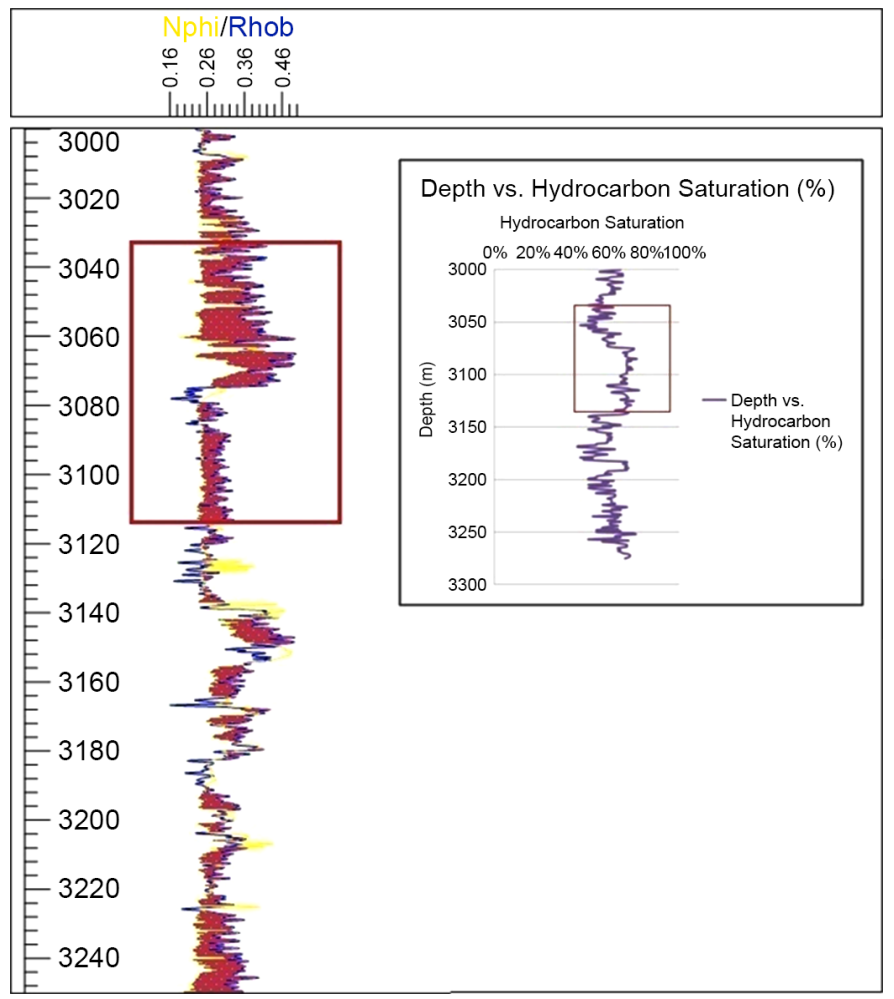

(a)

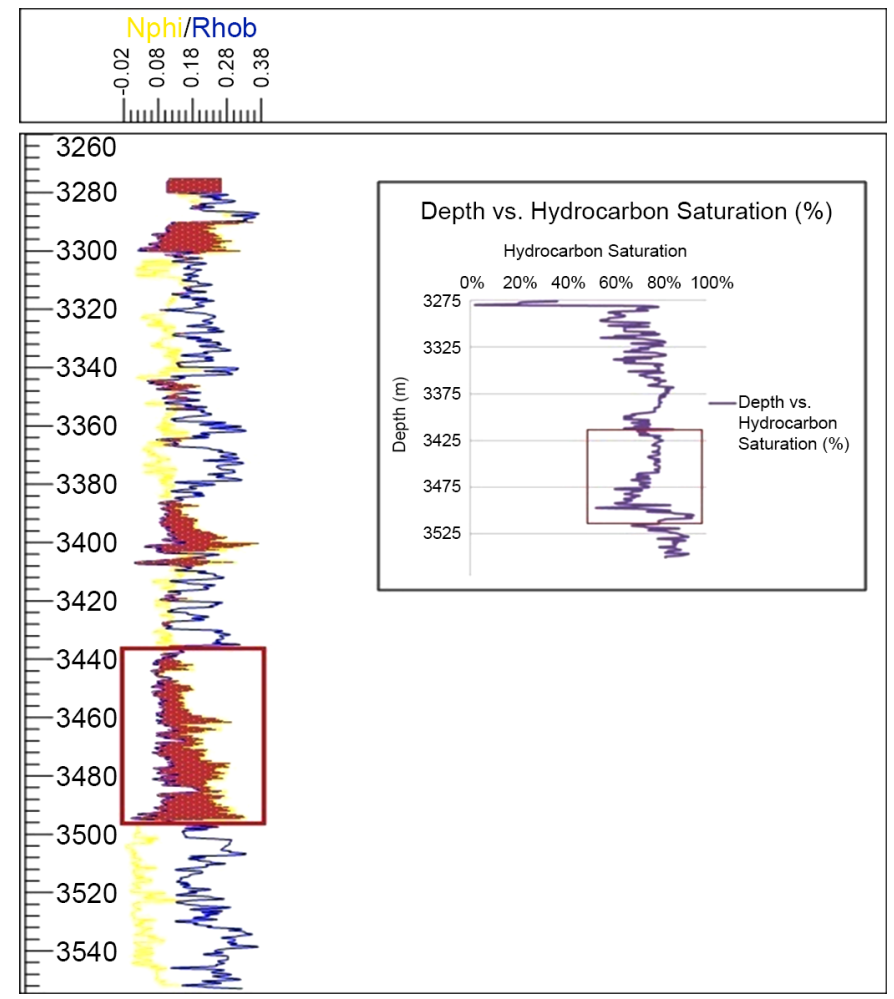

(b)

Figure 6. (a) Cross plot of Neutron Porosity and Density log (Left), depth vs. hydrocarbon saturation across zone-01 Lower Goru Formation (Right), (b) Cross plot of Neutron Porosity and Density log (Left), depth vs. hydrocarbon saturation across zone-02 Lower Goru Formation(Right).

\section{Acknowledgements}

Department of Earth and Environmental Sciences in Bahria University is acknowledged for the BS report that serves as foundation for this work. The Directorate General of Petroleum Concessions, Pakistan deserves acknowledgement for the well and seismic data. Petroleum Geosciences/Tectonics Laboratory supported by NRPU project 20-2062 at the Department of Earth Sciences in the COMSATS Institute of Information Technology is acknowledged for use of its facilities and financial support for the completion and publication of this research article.

\section{References}

[1] Ahmed, W., Azeem, A., Abid, M.F., Rasheed, A. and Aziz, K. (2013) Mesozoic Structural Architecture of the Middle Indus Basin, Pakistan-Controls and Implications. PAPG/SPE Annual Technical Conference, Islamabad, Pakistan, 1-13.

[2] Kadri, I.B. (1995) Petroleum Geology of Pakistan, 93-108.

[3] Krois, P., Mahmood, T. and Milan, G. (1998) Miano Field: A Case History of Model Driven Exploration. Pakistan Petroleum Convention, Islamabad, 112-131.

[4] Ahmad, N., Flink, P., Sturrock, S., Mahmood, T. and Ibrahim, M. (2012) Sequence Stratigraphy as Predictive Tool in Lower Goru Fairway, Lower and Middle Indus Platform, Pakistan. PAPG/ SPE Annual Technical Conference, Islamabad. 
[5] Jadoon, I.A.K., Lawrence, R.D. and Lillie, R.J. (1994). The Sulaiman Lobe, Pakistan: Geometry, Evolution, and Shortening of an Active Fold-and-Thrust Belt over Transitional Crust West of the Himalaya. American Association of Petroleum Geologist Bulletin, 78, 758-774.

[6] Raza, H.A., Ali, S.M. and Ahmed, R. (1990) Petroleum Geology of Kirthar Sub-Basin and Part of Kutch Basin. Pakistan Journal of Hydrocarbon Research, 2, 29-74.

[7] Jadoon, I.A.K. and Khawaja, A.A. (1997) Model Geometries of Extensional Faults: Implication on Structure of the Lower Indus Basin. Pakistan Journal of Hydrocarbon Research, 9, $35-47$.

[8] Wasimuddin, M., Jadoon, I.A.K., Weihua, W., Ebdon, C.C. and Akhter, S. (2005) Integration of the Image Logs in the Structural Analysis of the Zaur Field, Pakistan. PAPG/SPE Annual Technical Conference, Islamabad, 61-79.

[9] Munir, A., Asim, S., Bablani, S.A. and Asif, A.A. (2014) Seismic Data Interpretation and Fault Mapping in Badin Area, Sindh, Pakistan. Sindh University Research Journal (Sci. Ser.) 46, 133-142.

\section{Submit or recommend next manuscript to SCIRP and we will provide best service for you:}

Accepting pre-submission inquiries through Email, Facebook, LinkedIn, Twitter, etc. A wide selection of journals (inclusive of 9 subjects, more than 200 journals)

Providing 24-hour high-quality service

User-friendly online submission system

Fair and swift peer-review system

Efficient typesetting and proofreading procedure

Display of the result of downloads and visits, as well as the number of cited articles

Maximum dissemination of your research work

Submit your manuscript at: http://papersubmission.scirp.org/

Or contact ijg@scirp.org 